\title{
SELECTING PROPER PLANT SPECIES FOR MINE RECLAMATION USING FUZZY AHP APPROACH (CASE STUDY: CHADORMALOO IRON MINE OF IRAN)
}

\author{
WYBÓR GATUNKÓW ROŚLIN DO WYKORZYSTANIA W REKULTYWACJI \\ TERENÓW GÓRNICZYCH Z WYKORZYSTANIEM ELEMENTÓW LOGIKI ROZMYTEJ \\ I METODY AHP - ANALYTIC HIERARCHY PROCESS \\ (STUDIUM PRZYPADKU: KOPALNIA RUD ŻELAZA CHADORMALOO W IRANIE)
}

\begin{abstract}
This paper describes an effective approach to select suitable plant species for reclamation of mined lands in Chadormaloo iron mine which is located in central part of Iran, near the city of Bafgh in Yazd province. After mine's total reserves are excavated, the mine requires to be permanently closed and reclaimed. Mine reclamation and post-mining land-use are the main issues in the phase of mine closure. In general, among various scenarios for mine reclamation process, i.e. planting, agriculture, forestry, residency, tourist attraction, etc., planting is the oldest and commonly-used technology for the reclamation of lands damaged by mining activities. Planting and vegetation play a major role in restoring productivity, ecosystem stability and biological diversity to degraded areas, therefore the main goal of this research work is to choose proper and suitable plants compatible with the conditions of Chadormaloo mined area, providing consistent conditions for future use. To ensure the sustainability of the reclaimed landscape, the most suitable plant species adapted to the mine conditions are selected. Plant species selection is a Multi Criteria Decision Making (MCDM) problem. In this paper, a fuzzy MCDM technique, namely Fuzzy Analytic Hierarchy Process (FAHP) is developed to assist chadormaloo iron mine managers and designers in the process of plant type selection for reclamation of the mine under fuzzy environment where the vagueness and uncertainty are taken into account with linguistic variables parameterized by triangular fuzzy numbers. The results achieved from using FAHP approach demonstrate that the most proper plant species are ranked as Artemisia sieberi, Salsola yazdiana, Halophytes types, and Zygophyllum, respectively for reclamation of Chadormaloo iron mine.
\end{abstract}

Keywords: Chadormaloo iron mine, fuzzy AHP, mine reclamation, plant species

W pracy przedstawiono skuteczną metodę wyboru odpowiednich gatunków roślin do wykorzystania przy rekultywacji terenów górniczych na terenie kopalni rud żelaza Chadormaloo w środkowej części Iranu, w pobliżu miasta Bafgh, w prowincji Yazd. Po wyczerpaniu zasobów kopalni planowane jest całkowite jej zamkniecie i rekultywacja jej terenów. Rekultywacja terenów górniczych i ich wykorzystanie

\footnotetext{
DEPARTMENT OF MINING, FACULTY OF ENGINEERING, QAEMSHAHR BRANCH, ISLAMIC AZAD UNIVERSITY, QAEMSHAHR, IRAN. E-mail: arash.xer@gmail.com
} 
po zakończeniu wydobycia są kluczowymi zagadnieniami na etapie zamykania kopalni. Spośród rozmaitych scenariuszy rekultywacji terenów (sadzenie roślin, uprawy rolne, sadzenie lasów, przekształcenie w teren mieszkalny lub w atrakcje turystyczne), sadzenie roślin jest najstarszą i najczęściej stosowaną metodą rekultywacji terenów zniszczonych przez działalność górniczą. Nasadzenia i roślinność odgrywają kluczowa role w odtworzeniu produktywności terenu, przyczyniają się do stabilizacji ekosystemów i wnoszą bio-różnorodność na zdegradowane tereny. Stąd też głównym celem obecnych badań jest dobór najbardziej odpowiednich roślin dostosowanych do warunków panujących na terenie obecnej kopalni rud żelaza Chadormaloo, tym samym umożliwiając ponowne tych terenów wykorzystywanie w przyszłości. W celu zapewnienia długotrwałego charakteru krajobrazu, konieczny jest dobór odpowiednich roślin, dostosowanych do warunków panujących na terenie kopalni. Dobór gatunków roślin jest zagadnieniem decyzyjnym, wielo-kryterialnym (MCDM - Multi Criteria Decision Making). W niniejszej pracy przedstawiono metodę wyboru opartą o elementy logiki rozmytej FAHP (Fuzzy Analytic Hierarchy Process) do wykorzystania przez projektantów oraz kierownictwo kopalni i Chadormaloo przy wyborze odpowiednich roślin do rekultywacji terenów w środowisku charakteryzowanym przez parametry rozmyte. Metoda pozwala na uwzględnienie niejasności i niepewności, zmienne językowe są sparametryzowane przy wykorzystaniu liczb trójkątnych. Wyniki uzyskane dzięki wykorzystaniu metody FAHP pokazują, że przy rekultywacji terenów kopalni w Chadormaloo najbardziej odpowiednimi gatunkami roślin będą kolejno: Artemisia sieberi, Salsola yazdiana, Halophytes oraz Zygophyllum.

Słowa kluczowe: kopalnia rud żelaza Chadormaloo, metoda AHP z elementami logiki rozmytej, rekultywacja terenów górniczych, gatunki roślin

\section{Introduction}

Mine closure, followed by the process of mine reclamation, is the $4^{\text {th }}$ and last phase of mine planning after phases of planning (Laurence, 2001, 2006). After a mine's deposit was excavated, that mine should be closed and the damaged areas need to be rehabilitated and reclaimed rapidly to reduce the environmental impacts of mining operations. Mine reclamation plays a major role in the sustainable development of mining activities by establishing the environmental conditions necessary to support social (e.g. recreation), economic (e.g. forestry, agriculture) development (Akbari et al., 2006).

As for reclamation process, planting and revegetation is regarded as an appropriate option because it is a primarily important step to any further use; that is, for any other land use such as agriculture, forestry, landscape, residency and tourist attraction, the region needs to be initially prepared particularly via primary planting in surrounding area (Xia et al., 2007). Therefore, the selection process of plant species is a major agent in attaining the goals of a mine reclamation project including health protection in terms of prevention of further land, water and air pollution which can affect indigenous people's health and lives, preparing suitable perspective for the region such as providing spectacular views and landscapes, economic benefits through cultivating agricultural products, the welfare for local people, protection of underground water supply and prevention of soil erosion (Osanloo, 2002).

Selecting the appropriate plant types is a Multiple Criteria Decision Making (MCDM) issue, and among efficient approaches used in MCDM, the Analytic Hierarchy Process (AHP) proposed by Saaty (1980), is a helpful method in selection process and has been used in many mining-related issues such as mining method selection, mining site selection, equipment selection, excavator selection, post mining land-use, etc (Akbari et al., 2006). This method is able to convert the components of a complex problem from their original qualitative forms to quantitative ones. For gaining this goal, the effective factors on plant type selection must be grouped at first step and then at next step, all factors in each group is weighted and scored. Consequently, 
the decision making methodology will be established multiplying weightings by scores (Saaty, 1980). Akbari et al. (2006) have selected post mining land use through AHP method in Sungun copper mine. Bangian and Osanloo (2008) have selected plant species for Sungun copper mine by traditional AHP method. Soltanmohammadi et al. (2010) have used combination of group versions of AHP and TOPSIS (Technique for Order Preference by Similarity to Ideal Solution) techniques to determine a preference ranking list for possible post mining land uses of a hypothetical mined land based on the Mined Land Suitability Analysis framework. The TOPSIS method was firstly proposed by Hwang and Yoon (1981). The basic concept of this method is that the chosen alternative should have the shortest distance from the positive ideal solution and the farthest distance from negative ideal solution. Positive ideal solution is a solution that maximizes the benefit criteria and minimizes cost criteria, whereas the negative ideal solution maximizes the cost criteria and minimizes the benefit criteria (Wang \& Elhag, 2006). In many cases, application of AHP method can be accompanied by other methods such as fuzzy logic. In the majority of cases, especially regarding qualitative criteria, AHP with crisp input data cannot conveniently meet expert's opinion in uncertain condition. That is why Fuzzy AHP is utilized, decreasing this deficit. Zadeh (1965) presented the fuzzy set theory for the first time to handle the unclarity of human's decision making. A set of fuzzy objects is a series with continuum grades of membership. This set is described through a function of membership attributed to each object with membership grade between 0 and 1 (Zadeh, 1965). Expanded form of a crisp set is considered as a fuzzy set. In crisp sets, full membership or non-membership of objects are only take into account, whereas fuzzy sets considered partial memberships. This means that an element can partially be a member of a fuzzy set (Ertuğrul \& Karakaşoğlu, 2006; 2008). Fuzzy approaches are influential tools for encountering uncertain issues in decision-making when complete or exact data is not available (Chien-Chang, 2011). Such methods are more remarkable when applied to complex phenomena which can't easily be depicted by conventional mathematical methods, particularly in the case of finding an appropriate solution (Bojadziev G. \& Bojadziev M., 1998). Currently, compared to classic theories, fuzzy methods are extensively used in various areas due to its capability to reflect real world (Ertuğrul \& Tuş, 2007; Rajput et al., 2011). Results achieved from modeling using fuzzy sets demonstrated that such methods can be considered as an effective way for formulating decision making issues where the information available is intellectual and misty (Zimmermann, 1992). In the approach used in this paper, namely fuzzy AHP, fuzzy numbers is used in the calculations instead of crisp numbers in AHP. Alavi et al. (2011) have selected proper plant types for Sarcheshmeh copper mine reclamation plan by fuzzy AHP method.

The aim of the present work is to select the proper plant species through a fuzzy AHP solution procedure. With that regard, Chadormaloo iron mine, one of the Iran's largest iron mine in Yazd province, considered as case study. It should be stated that there is still only a primary planting plan for reclamation of this mine based on experts' opinion and no decision has been made to select which kind of plants are suitable for this issue.

There are some previous studies conducted regarding the type of plant species for various purposes in Yazd region whose conditions are very similar to Chadormaloo conditions. Abolghasemi et al. (2004) reviewed the vegetation of the Behabad-Raver territory in Yazd province. Dashtkian et al. (2000, 2001, 2002), in separate researches, investigated on the resistant plant species in Meybod, Yazd, Ardakan-Abadeh districts. Ghaderi, et al. (2003) studied on the vegetation feasibility of Tabas region and following the investigations in this region, Reyhan and Amiraslani (2006) studied on the relationship between vegetation and physicochemical properties of soil in Tabas area. Initial step in selecting plant species for mine reclamation begins with 
regard to primary factors. Candidate species for reclamation of Chadormaloo mine (pistachio, Amygdalus scoparia, Astragalus, Ephedra, Artemisia sieberi, Salsola yazdiana, Halophytes types, and Zygophyllum) should meet essential factors including type of post mining land use, regional climate condition and soil type. In the following sections, the selection procedure of plant species for Chadormaloo iron mine is presened.

\section{Methods}

\subsection{Fuzzy Theory}

Adequate knowledge and comprehensive database on a number of different problems are requested to analyse critical infrastructures. There are a close relationship between complexity and certainty, so that; increasing the complexity lead to decrease the certainty. Fuzzy logic, introduced by Zadeh (1965), can consider uncertainty and solve problems where there are no sharp boundaries and precise values. Fuzzy logic provides a methodology for computing directly with words (Zadeh, 1965).

Fuzzy set theory is a powerful tool to handle imprecise data and fuzzy expressions that are more natural for humans than rigid mathematical rules and equations (Bellman \& Zadeh, 1977; Vahdani \& Hadipour, 2010; Ertugrul, 2011).

A fuzzy set is general form of a crisp set. A fuzzy number belongs to the closed interval 0 and 1 , which 1 addresses ful membership and 0 expresses non-membership. Whereas, crisp sets only allow 0 or 1 . There are different types of fuzzy numbers that can be utilised based on the situation. It is often convenient to work with triangular fuzzy numbers (TFNs) because they are computed simply, and are useful in promoting representations and information processing in a fuzzy environment (Van Laarhoven \& Pedrycz, 1983; Bojadziev \& Bojadziev, 1998; Deng, 1999; Ertugrul \& Tuş, 2007; Torlak et al., 2011).

A fuzzy number $\widetilde{A}$ on $R$ can be a TFN if its membership function $\mu_{\widetilde{A}}(x): R \rightarrow[0,1]$ which is defined as follows:

$$
\mu_{\tilde{A}}(x)=\left\{\begin{array}{lc}
0, & x \leq a \\
(x-a) /(b-a), & a \leq x \leq b \\
(c-x) /(c-b), & b \leq x \leq c \\
0, & \text { otherwise }
\end{array}\right.
$$

Let $\tilde{A}=\left(a_{1}, a_{2}, a_{3}\right)(+), \tilde{B}\left(b_{1}, b_{2}, b_{3}\right)$ be two fuzzy numbers, so their mathematical relations expressed as:

$$
\begin{gathered}
\tilde{A}(+) \tilde{B}=\left(a_{1}, a_{2}, a_{3}\right)(+)\left(b_{1}, b_{2}, b_{3}\right)=\left(a_{1}+b_{1}, a_{2}+b_{2}, a_{3}+b_{3}\right) \\
\tilde{A}(-) \tilde{B}=\left(a_{1}, a_{2}, a_{3}\right)(-)\left(b_{1}, b_{2}, b_{3}\right)=\left(a_{1}-b_{3}, a_{2}-b_{2}, a_{3}-b_{1}\right) \\
\tilde{A}(\times) \tilde{B}=\left(a_{1}, a_{2}, a_{3}\right)(\times)\left(b_{1}, b_{2}, b_{3}\right)=\left(a_{1} b_{1}, a_{2} b_{2}, a_{3} b_{3}\right) \\
\tilde{A}(\div) \tilde{B}=\left(a_{1}, a_{2}, a_{3}\right)(\div)\left(b_{1}, b_{2}, b_{3}\right)=\left(a_{1} / b_{3}, a_{2} / b_{2}, a_{3} / b_{1}\right)
\end{gathered}
$$




\subsection{Fuzzy AHP methodology}

Analytical hierarchy process (AHP) was developed primarily by Saaty (1980) and is able to solve the decision making problems (Vaida and Kumar, 2006). AHP can decompose any complex problem into several sub-problems in terms of hierarchical levels where each level represents a set of criteria or attributes relative to each sub-problem. AHP utilizes three principles to solve problems (Aydogan, 2011): (a) structure of the hierarchy, (b) the matrix of pair-wise comparison ratios, and (c) the method for calculating weights. AHP summarises the results of pair-wise comparisons in a matrix of pair-wise comparisons (Kahraman, 2008).

Different fuzzy AHP methods are proposed by various authors (Van Laarhoven and Pedrycz, 1983; Buckley, 1985; Boender et al., 1989; Chang 1992, 1996). These methods apply a systematic procedure to prioritize the criteria and alternatives by using the concepts of fuzzy set theory and hierarchical structure analysis. In this paper, Chang's extent analysis method (Chang, 1996) is utilized because the steps of this approach are relatively easier than the other fuzzy AHP techniques.

Assume $X=\left\{x_{1}, x_{2}, x_{3}, \ldots, x_{n}\right\}$ be an object set, and $G=\left\{g_{1}, g_{2}, g_{3}, \ldots, g_{n}\right\}$ be a goal set. According to the method of Chang's extent analysis, each object is taken and extent analysis for each goal, $g_{i}$, is performed, respectively. Therefore, $m$ extent analysis values for each object can be obtained, with the following signs (Chang, 1996):

$$
M_{g i}^{1}, M_{g i}^{2}, \ldots, M_{g i}^{m}, \quad i=1,2,3, \ldots, n
$$

where all the $M_{g i}^{j}, j=1,2,3, \ldots, m$ are TFNs.

The steps of Chang's extent analysis can be given as following:

Step 1: The value of fuzzy synthetic context with respect to $i^{\text {th }}$ object is define as (Eq. 6):

$$
S_{i}=\sum_{j=1}^{m} M_{g i}^{j} \otimes\left[\sum_{i=1}^{n} \sum_{j=1}^{m} M_{g i}^{j}\right]^{-1}
$$

To obtain $\sum_{j=1}^{m} M_{g i}^{j}$ (Fuzzy Summation of Row), perform the fuzzy addition operation of $m$ extent analysis values for a particular matrix such that (Eq. 7):

$$
\sum_{j=1}^{m} M_{g i}^{j}=\left(\sum_{j=1}^{m} l_{j}, \sum_{j=1}^{m} m_{j}, \sum_{j=1}^{m} u_{j}\right)
$$

And to obtain $\left[\sum_{i=1}^{n} \sum_{j=1}^{m} M_{g i}^{j}\right]^{-1}$, perform the fuzzy addition operation of $M_{g i}^{j}, j=1,2,3, \ldots, m$ values such that (Eq. 8): (Summation of Column)

$$
\sum_{i=1}^{n} \sum_{j=1}^{m} M_{g i}^{j}=\left(\sum_{i=1}^{m} l_{i}, \sum_{i=1}^{m} m_{i}, \sum_{i=1}^{m} u_{i}\right)
$$


And then compute the inverse of the vector in Eq. 9 such that:

$$
\left[\sum_{i=1}^{n} \sum_{j=1}^{m} M_{g i}^{j}\right]^{-1}=\left(\frac{1}{\sum_{i=1}^{n} u_{i}}, \frac{1}{\sum_{i=1}^{n} m_{i}}, \frac{1}{\sum_{i=1}^{n} l_{i}}\right)
$$

Step 2: The degree of possibility of $M_{2}=\left(l_{2}, m_{2}, u_{2}\right) \geq M_{1}=\left(l_{1}, m_{1}, u_{1}\right)$ is defined as:

$$
V\left(M_{2} \geq M_{1}\right)=\left(y \geq x^{\sup }\left[\min \left(\mu_{M_{1}}(x), \mu_{M_{2}}(y)\right)\right]\right)
$$

And can be equivalently expresses as follows:

$$
\begin{gathered}
V\left(M_{2} \geq M_{1}\right)=\operatorname{hgt}\left(M 1 \cap M_{2}\right)=\mu_{M_{2}}(d) \\
\left(M_{2} \geq M_{1}\right)=\left\{\begin{array}{cc}
1 & \text { if } m_{2} \geq m_{1} \\
0 & \text { if } l_{1} \geq u_{2} \\
l_{1}-u_{2} /\left(m_{2}-u_{2}\right)-\left(m_{1}-l_{1}\right) \text { otherwise }
\end{array}\right.
\end{gathered}
$$

where $d$ is the ordinate of highest intersection point $D$ between $\mu_{M_{1}}$ and $\mu_{M_{2}}$ (see Fig. 1). To compare $M_{1}$ and $M_{2}$, we need both the values of $V\left(M_{1} \geq M_{2}\right)$ and $V\left(M_{2} \geq M_{1}\right)$.

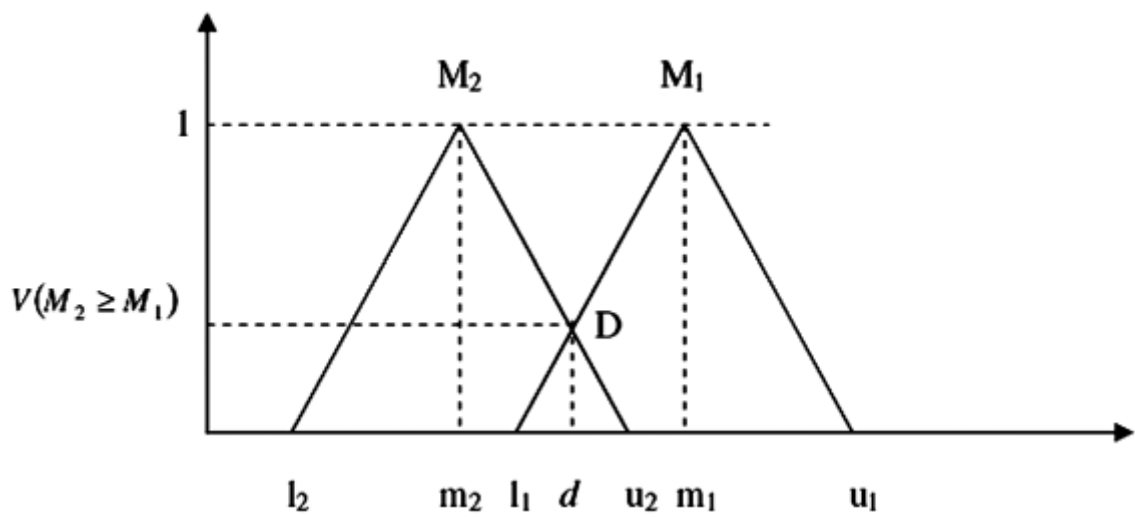

Fig. 1. The intersection between $M_{1}$ and $M_{2}$ (Chang, 1996)

Step 3: The degree of possibility for a convex fuzzy number to be greater than $k$ convex numbers $M_{i}(i=1,2, \ldots, k)$ can be defined by:

$$
\begin{aligned}
V\left(M \geq M_{1}, M_{2}, \ldots, M_{k}\right) & =V\left[\left(M \geq M_{1}\right) \text { and }\left(M \geq M_{2}\right)\right. \text { and } \\
\ldots & \text { and } \left.\left(M \geq M_{k}\right)\right]=\min \left(M \geq M_{1}\right) \quad i=1,2,3, \ldots, k
\end{aligned}
$$

Assume that

$$
D^{\prime}\left(A_{i}\right)=\min V\left(S_{i} \geq S_{k}\right)
$$


for $k=1,2, \ldots, n ; k \neq i$. Then the weight vector is given by

$$
W^{\prime}=\left(d^{\prime}\left(A_{1}\right), d^{\prime}\left(A_{2}\right), \ldots, d^{\prime}\left(A_{n}\right)\right)^{T}
$$

where $A_{i}(i=1,2, \ldots, n)$ are $\mathrm{n}$ elements.

Step 4: Via normalization, the normalizedweght vectors are

The normalized weight vectors are obtained through normalization process, as below (Eq. 16):

$$
W^{\prime}=\left(d^{\prime}\left(A_{1}\right), d^{\prime}\left(A_{2}\right), \ldots, d^{\prime}\left(A_{n}\right)\right)^{T}
$$

where $W$ is a non-fuzzy number.

Step 5: Determination of alternatives of final weight, as below:

$$
\begin{aligned}
& A_{1}=\left(A_{1} \text { to } C_{1} \times C_{1} \text { to } G O A L\right)+\left(A_{1} \text { to } C_{2} \times C_{2} \text { to } G O A L\right)+ \\
& +\left(A_{1} \text { to } C_{3} \times C_{3} \text { to } G O A L\right)+\ldots+\left(A_{1} \text { to } C_{n} \times C_{n} \text { to } G O A L\right)
\end{aligned}
$$

where $n$ is the number of criteria.

\section{Application of FAHP}

\subsection{Study Area}

Chadormaloo iron mine, as a case study in this research, is viewed as one of the largest mines in Iran which has a comprehensive plan with special attention to closure plan. Among reclamation alternatives for Chadormaloo mine, planting and revegetation is the most appropriate option selected by local experts due to its suitability and adaptability to the conditions of Chadormaloo mine site including geographical situation, soil type and climate condition (Dashtakian \& Khosroshahi, 2002).

The mine area is a part of Bafgh-Saghand iron field and is situated at $55^{\circ} 30^{\prime}$ east longitude, $32^{\circ} 17^{\prime}$ north latitude and $1450 \mathrm{~m}$ altitude. From a geological point of view, Chadormaloo is the biggest ever mine in the central Iran which is located in a big geyser zone. According to statistical results from previous investigations conducted by Dashtakian $(2000 ; 2001 ; 2002)$, the mine site is located at a desert terrain with dry condition, severe climate condition (cold winters with minimum temperature of $-16^{\circ} \mathrm{C}$ and hot summers with maximum temperature of $45^{\circ} \mathrm{C}$ ) and annual average temperature in the area is $22.4^{\circ} \mathrm{C}$. Annual average rainfall in the area is $107 \mathrm{~mm}$. Hence, candidate plants should be adaptable to such climate condition.

According to the results of soil experiments, the acidity of the soil was found at very high level and it is due to presence of large amount of $\mathrm{Fe}$ (Grade of Fe in iron deposit varies from $20 \%$ to nearly $58 \%$ ). As a result, candidate plant species need to be consistent and resistant enough against such acidic condition. These plants should also be able to absorb toxic elements and impede pollution of surrounding residential areas (Dashtakian, 2000, 2001, 2002).

Regarding existing vegetation types in the region, Mousaei Sanjerehei et al. (2013) investigated 9 sites (vegetation types) in the surrounding rangelands. Within each site, four parallel $100 \mathrm{~m}$ transects were located. The vegetation cover was estimated in 15 equidistantly-located $2 \times 2.5 \mathrm{~m}$ quadrats along each transect (60 quadrats in each vegetation type). In the middle of each transect, a soil sample was taken between $0-10 \mathrm{~cm}$ and $10-80 \mathrm{~cm}$ layers $(72$ samples 
in 9 vegetation types). Soil attributes measured include electrical conductivity (ECe) (measured with a conductivity meter), nitrogen (determined using the Kjeltec system), $\mathrm{pH}$ in the saturation extract (determined with a $\mathrm{pH}$ meter), texture (determined by a Bouyoucos hydrometer), saturation moisture (measured by the weighing method), organic carbon (measured using Walkely and Black titration), lime (determined based on total neutralizing value), gypsum (determined using the acetone method), available water (obtained using the retention curve program based on soil texture and bulk density), and gravel (particles with a diameter $>2 \mathrm{~mm}$ ) (Mousaei Sanjerehei et al., 2013). Edaphic characteristics of the study sites are presented in Table 1. The floristic list and cover percentage of plant species are shown in Table 2.

Edaphic characteristics of the study sites (Mousaei Sanjerehei et al., 2013)

\begin{tabular}{|c|c|c|c|c|c|c|c|c|c|c|c|c|c|c|}
\hline 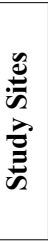 & 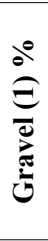 & 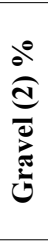 & 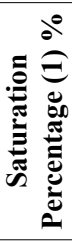 & 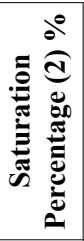 & $\begin{array}{l}Ð \\
\frac{1}{2}\end{array}$ & $\begin{array}{l}\text { a } \\
\frac{1}{2}\end{array}$ & 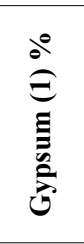 & 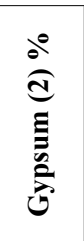 & 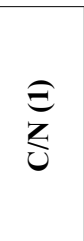 & $\begin{array}{l}\widehat{a} \\
z \\
\text { z }\end{array}$ & 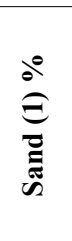 & 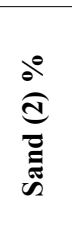 & 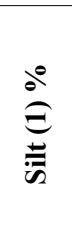 & $\frac{d^{0}}{\stackrel{a}{a}}$ \\
\hline 1 & 17 & 19 & 36.6 & 36 & 7.3 & 7.83 & 0 & 0 & 5.3 & 4.76 & 69.4 & 73.4 & 21.3 & 17.3 \\
\hline 2 & 14 & 21 & 32 & 28.2 & 7.64 & 7.31 & 61.74 & 63.43 & 3.94 & 75.71 & 66.4 & 81.4 & 23.3 & 11.3 \\
\hline 3 & 12 & 18 & 35 & 39 & 7.43 & 7.31 & 2.06 & 0 & 11.87 & 3.51 & 63.4 & 68.4 & 26.3 & 21.3 \\
\hline 4 & 12 & 21 & 39 & 27 & 7.38 & 7.43 & 0 & 29.4 & 1.38 & 2.76 & 57.4 & 83.4 & 33.3 & 11.3 \\
\hline 5 & 11 & 19 & 37 & 34 & 7.59 & 7.78 & 0 & 0 & 9.5 & 4.52 & 63.4 & 77.4 & 27.3 & 17.3 \\
\hline 6 & 11 & 14 & 39 & 32 & 7.9 & 7.75 & 0 & 0 & 11.75 & 4.06 & 53.4 & 70.4 & 37.3 & 22.3 \\
\hline 7 & 16 & 9 & 46 & 32 & 7.06 & 7.72 & 1.01 & 0.11 & 57.1 & 21.07 & 71.4 & 77.4 & 21.3 & 16.3 \\
\hline 8 & 8 & 14 & 38 & 36.4 & 7.19 & 7.16 & 0 & 0 & 6 & 3.45 & 43.4 & 63.4 & 47.3 & 27.3 \\
\hline 9 & 8 & 10 & 36 & 36 & 7.67 & 7.69 & 0 & 0.21 & 16.52 & 12.45 & 41.4 & 41.4 & 46.9 & 45.3 \\
\hline
\end{tabular}

TABLE 1 (Continued)

Edaphic characteristics of the study sites (Mousaei Sanjerehei et al., 2013)

\begin{tabular}{|c|c|c|c|c|c|c|c|c|c|c|}
\hline 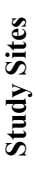 & 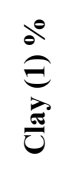 & 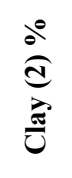 & 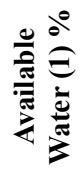 & 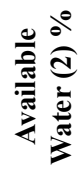 & 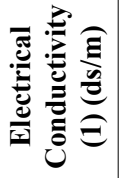 & 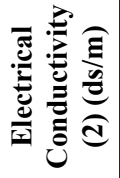 & 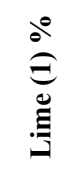 & 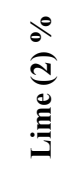 & 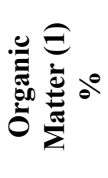 & 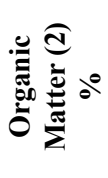 \\
\hline 1 & 9.3 & 9.3 & 15.5 & 8.68 & 16 & 1.98 & 17.57 & 13.57 & 0.0758 & 0.275 \\
\hline 2 & 10.3 & 7.3 & 10.27 & 5.11 & 3.24 & 6.01 & 9.07 & 9.07 & 0.275 & 0.091 \\
\hline 3 & 10.3 & 10.3 & 10.83 & 9.88 & 16.5 & 30.37 & 23.3 & 18.57 & 0.229 & 0.229 \\
\hline 4 & 9.3 & 5.3 & 12.09 & 3.26 & 10.7 & 5.3 & 22.8 & 13.5 & 0.107 & 0.153 \\
\hline 5 & 9.3 & 5.3 & 10.8 & 6.86 & 0.673 & 1.17 & 22.8 & 23.57 & 0.458 & 0.229 \\
\hline 6 & 9.3 & 7.3 & 13.07 & 9.29 & 0.78 & 1.047 & 34.8 & 43.3 & 0.427 & 0.382 \\
\hline 7 & 7.3 & 6.3 & 8.94 & 6.69 & 0.72 & 0.87 & 12.82 & 15.3 & 0.275 & 0.305 \\
\hline 8 & 9.3 & 9.3 & 16.92 & 10.99 & 1.01 & 0.52 & 34.8 & 50.32 & 0.275 & 0.382 \\
\hline 9 & 11.7 & 13.3 & 17.13 & 16.6 & 0.624 & 1.6 & 20.32 & 20.07 & 0.917 & 0.962 \\
\hline
\end{tabular}

Signs 1 and 2 indicate the first $(0-10 \mathrm{~cm})$ and the second $(10-80 \mathrm{~cm})$ soil layers, respectively. Organic matter was calculated by multiplying \% organic carbon by a factor of 1.724 . 
The cover percentage of the plant species in the study sites (Mousaei Sanjerehei et al., 2013)

\begin{tabular}{|c|c|c|c|c|c|c|c|c|c|c|c|c|c|c|}
\hline 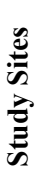 & 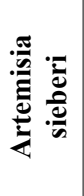 & 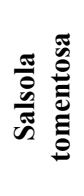 & 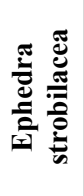 & 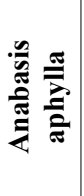 & 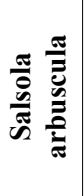 & 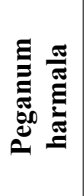 & 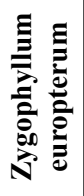 & 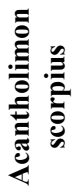 & لِّ & 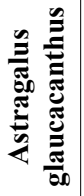 & 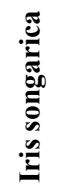 & 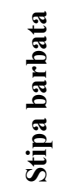 & 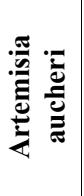 & 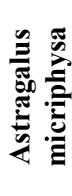 \\
\hline 1 & 6.6 & 1.1 & - & - & - & - & - & - & - & - & - & - & - & - \\
\hline 2 & 5.1 & - & 4.8 & - & - & - & - & - & - & - & - & - & - & - \\
\hline 3 & 2.9 & - & - & 3.3 & - & - & - & - & - & - & - & - & - & - \\
\hline 4 & 9 & - & - & - & 1.4 & - & - & - & - & - & - & - & - & - \\
\hline 5 & 5.2 & - & - & - & - & 2.62 & - & - & - & - & - & - & - & - \\
\hline 6 & 12.9 & - & - & - & - & - & 2.6 & 1.9 & - & - & - & - & - & - \\
\hline 7 & 10.4 & - & - & - & - & - & - & - & 2.1 & 0.52 & 2 & - & - & - \\
\hline 8 & 16.6 & - & - & - & - & - & - & 2.1 & - & - & 2.7 & 0.61 & - & - \\
\hline 9 & - & - & - & - & - & - & - & - & - & - & - & 0.7 & 23 & 1.5 \\
\hline
\end{tabular}

According to the edaphic characteristics of study area, A.aucheri (and A.microphysa as the second most abundant species in the A.aucheri type) were characterized by high silt and organic matter in both soil layers, clay and available water in the second layer, high elevation, and slope. These factors had a lesser effect on the S.barbata cover. The A.aphylla cover was mostly associated with high soil salinity (ECe) in both layers and saturation moisture in the second layer. E.strobilacea was characterized by a high content of gypsum in both layers, $\mathrm{C} / \mathrm{N}$ in the second layer, and a low saturation moisture content in both layers. The cover of P.harmala, A.scorpius, Z.europterum, I.songarica, S.tomentosa, A.sieberi, S.arbuscula, E.ceratoides and A.glaucacanthus was mainly affected by a high rate of sand in both layers (Mousaei Sanjerehei et al., 2013).

\subsection{Fuzzy AHP approach for selecting the plant species in Chadormaloo iron mine}

To reach the objective, the selection process of suitable alternatives (candidate plant species) starts through evaluating the whole alternatives in accordance with primary factors. As cited before in introduction section, primary factors include type of post-mining land-use, regional climate condition and soil type. With this respect, some questionnaires were prepared, distributed and then filled out according to expert's oral judgment. Importance levels and diverse alternatives for plant types based on primary factors were subsequently obtained. Table 3 shows a result of such investigations toward prevention pollution criterion. It should be stated that other alternatives questionnaires are not represents due to avoiding repetitive and excessive explanations. Table 4 lists importance coefficients which can convert qualitative judgments to quantitative ones (fuzzy numbers).

Priorities of primary selected species are described on the basis of the secondary factors by a MCDM model using Fuzzy AHP method. Secondary factors (evaluation criteria) include $\mathrm{C} 1)$ landscape of the region, $\mathrm{C} 2$ ) resistance against diseases and insects, C3) consistency and method of growth, C4) availability, C5) economic efficiency, C6) protection of soil and storing 
water, C7) pollution prevention. In addition, there are four alternatives (according to the highest rankings achieved from the questionnaires) including A1: Artemisia sieberi, A2: Zygophyllum, A3: Salsola yazdiana, A4: Halophytes types.

TABLE 3

Alternatives questionnaire toward prevention pollution criterion

\begin{tabular}{|c|c|c|c|c|c|}
\hline \hline Very high & High & Medium & Low & Very low & Importance in C7/Alternative \\
\hline & & $*$ & & & pistachio \\
\hline & & $*$ & & & Amygdalus scoparia \\
\hline & & $*$ & & & Ephedra \\
\hline & & $*$ & & & Astragalus \\
\hline
\end{tabular}

Preference values for the questionnaires

\begin{tabular}{|c|c|}
\hline \hline Quality Judge & Fuzzy numbers \\
\hline Very low & $1,2,3$ \\
\hline Low & $2,3,5$ \\
\hline Average & $3,5,7$ \\
\hline High & $5,7,9$ \\
\hline Extreme & $7,9,9$ \\
\hline
\end{tabular}

The algorithm of Fuzzy AHP approach is presented and sammarised step by step as follows:

\section{A. Making Hierarchical Structure of the Problem}

The criteria and alternatives can be ruled as a hierarchical structure of the problem, shown in Fig. 2.

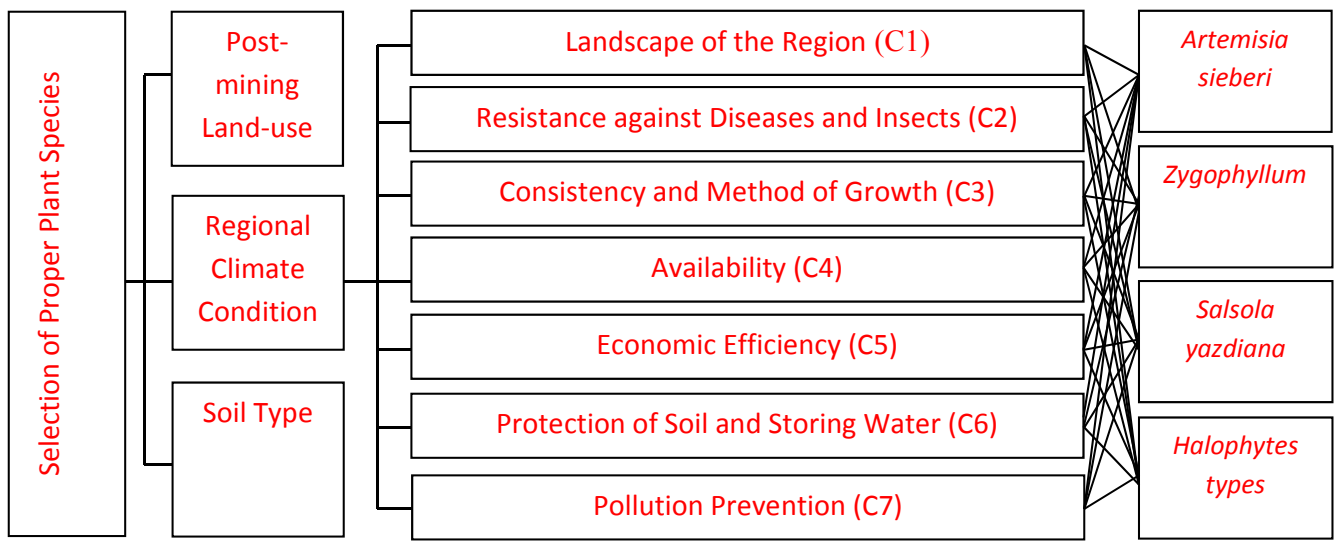

Fig. 2. Hierarchical structure of the problem 


\section{B. Making Comparison Dual Matrix}

Decision-makers prepared questionnaires forms and then with division against other importance carry out pair-wise comparison. Decision-makers use the linguistic variables, to evaluate the ratings of alternatives with respect to each criterion and they converted into triangular fuzzy numbers. Among the various shapes of fuzzy number, triangular fuzzy number (TFN) is the most popular one; hence, these TFNs have been used through the analyses. Fuzzy numbers are defined arbitrarily as very low $[1,2,3]$, low $[2,3,5]$, medium $[3,5,7]$, high $[5,7,9]$, very high $[7,9,9]$ that are shown Table 4.

\section{Determination of any Matrix Relative Weight}

After making fuzzy pair-wise comparison matrix and according to the FAHP method, synthesis values must firstly be determined. In this regard, values with respect to each goal are calculated like in Eq. (6) according to extent analysis synthesis. These fuzzy values are compared using Eq. (12), and next values are obtained. Then priority weights (Min) are calculated using Eqs. (14, 15).

After the normalization of these values, priority weights of alternatives for each criterion are determined by making the same calculation.

\section{Determination of Alternatives Final Weight (Selection of Plant Types)}

This can be carried out by conflation of scores. By using of Eq. (17), the highest priority weight is selected as a most appropriate plant species in order to mine reclamation.

\section{Results}

As mentioned before, after making hierarchical structure of the problem and preparing questionnaires, decision-makers used the linguistic variables, to evaluate the ratings of alternatives with respect to each criterion and they converted into triangular fuzzy numbers. Then, a comprehensive pair-wise comparison matrix is built. One of these pair-wise comparisons with respect to $\mathrm{C} 7$ (Pollution prevention) is shown below in Table 5 as an example.

TABLE 5

The Alternatives fuzzy dual comparison matrix toward together, with respect to $\mathrm{C} 7$ (Pollution prevention)

\begin{tabular}{|c|c|c|c|c|c|}
\hline \hline Weight & $\mathbf{A 4}$ & $\mathbf{A 3}$ & $\mathbf{A 2}$ & $\mathbf{A 1}$ & $\mathbf{C 7}$ \\
\hline 0.250 & $1,1,1$ & $1,1,1$ & $1,1,1$ & $1,1,1$ & $\mathrm{~A} 1$ \\
\hline 0.250 & $1,1,1$ & $1,1,1$ & $1,1,1$ & $1,1,1$ & $\mathrm{~A} 2$ \\
\hline 0.250 & $1,1,1$ & $1,1,1$ & $1,1,1$ & $1,1,1$ & $\mathrm{~A} 3$ \\
\hline 0.250 & $1,1,1$ & $1,1,1$ & $1,1,1$ & $1,1,1$ & $\mathrm{~A} 4$ \\
\hline
\end{tabular}

From Table 5, values with respect to goal (here, for example, pollution prevention) are calculated like in Eq. (6) according to extent analysis synthesis. These fuzzy values are compared using Eq. (12), and next values are obtained. Then priority weights (Min) are calculated using Eqs. $(14,15)$. 
After the normalization of these values, priority weights respect to pollution prevention are calculated. The priority weights of the criteria are then determined and the priority of the alternatives will be specified for each criterion. From the pair-wise comparisons matrixes based on decision-makers> opinion for four alternatives, evaluation matrixes are also generated. Similarly, priority weights of alternatives for each criterion are determined by making the same calculation.

Then, by using of Eq. (17), alternative A1: Artemisia sieberi - the highest priority weight - is selected as a most appropriate plant species in order to mine reclamation. The ranking order of the alternatives with fuzzy AHP method is A1: Artemisia sieberi > A3: Salsola yazdiana > A4: Halophytes types $>$ A2: Zygophyllum, shown in Fig. 3.

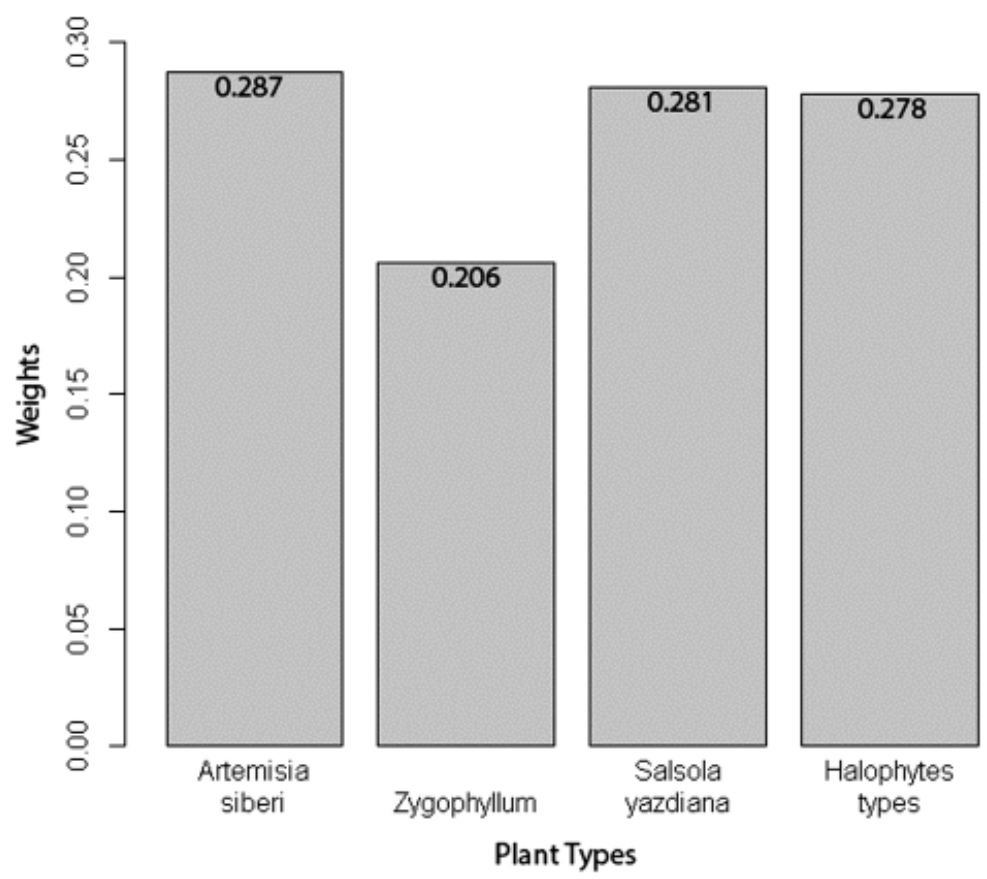

Fig. 3. Priority of plant types for reclamation of Chadormaloo iron mine determined by Fuzzy AHP method

\section{Discussion}

The main objective of this research study was to select the proper plant types for mine reclamation. However, the author tried to apply a powerful MCDM approach, namely Fuzzy AHP, for choosing the plant species as another goal of this work.

Fuzzy AHP approach is an appropriate method for selecting plant species or other multicriteria decision-making problems. However, this method has some limitations and demerits as mentioned below:

- Through fuzzy AHP, decision-maker is only requested to give judgments about either the relative importance of one criterion against another or its preference of one alterative on 
one criterion against another. However, when the number of alternatives and criteria grows, the pair-wise comparison process becomes cumbersome, and the risk of inconsistencies grows.

- In the extent analysis of fuzzy AHP, the priority weights of criterion or alternative can be equal to zero. In this situation, we do not take this criterion or alternative into consideration. This is the one of the drawbacks of this method.

Companies should choose the appropriate method for their problem according to the situation and the structure of the problem they have. In future studies, other multi-criteria methods like fuzzy TOPSIS, fuzzy PROMETHEE and ELECTRE can be used to handle plant species selection process.

As for selected plant species, it should be stated that proper selection of plant types for mine reclamation is closely related to a variety of edaphic and topographic factors as well as climate condition. Among the soil attributes, texture, available water, saturation moisture, organic matter, gypsum, ECe and $\mathrm{C} / \mathrm{N}$ ratio greatly affected the distribution and selection criteria of plants. Moreover, the relation between vegetation and environmental factors stems from the ecological requirements, tolerance range, and habitat conditions of plants (Mousaei Sanjerehei et al., 2013). Therefore, the plant species were chosen on the basis of mentioned criteria. The determination of plant species, indicating environmental circumstances in a given site, will lead to the efficient selection of adaptable species for the improvement and reclamation of that site and similar areas. With this respect, the selected species will be adaptable to Chadormaloo mine conditions and appropriate for reclamation of the mine.

Artemisia sieberi is the most common plant in the area; hence it was regarded as an important alternative for reclamation plan due to its compatibility with the conditions of the site particularly low humidity and salinity. This species can also have some merits in terms of preventing soil erosion and grazing. Zygophyllum and Salsola yazdiana are highly adaptable to the climate conditions of the mine site, ranging from relatively moderate to arid climate. Halophytes types also have a great resistance against salinity and as a result they were considered as a high potential candidate for reclamation of the mine. Moreover, because the role availability of plant plays in the selection of preferences is hard to ignore, available species were just chosen.

\section{Conclusions}

Decision-makers face up to the uncertainty and vagueness from subjective perceptions and experiences in the decision making process. We have demonstrated that the Multi Criteria Decision Making (MCDM) approaches such as fuzzy AHP is a suitable method to select plant species for mine reclamation. This method was efficient to reduce the uncertainty and vagueness of subjective perceptions and ensure logical decision making. MCDM effectively reflected the experiences of decision-maker.

The main objective of this research study was to select the proper plant type for planting the mined land as a reclamation plan to protect the environment from impacts of mining operations. In this regard, Chadormaloo iron mine, one of the Iran's biggest iron mines, was chosen as a case study. The surrounding area of Chadormaloo iron mine was firstly surveyed in order to find the best plant types compatible with such ecological fit determined through a series of sampling and tests on soil, water and native plants growing in the area by Dashtakian $(2000 ; 2001 ; 2002)$ and 
Mousaei Sanjerehei et al. (2013). The major plant types were then selected based on reclamation plan's primary criteria such as type of post mining land use, regional climate condition, type of soil. Afterwards, plant type selection has been conducted using fuzzy AHP approach with special attention to establishment of mine closure plan and environmental measures. Through the analyses, some factors including landscape of the region, resistance against diseases and insects, consistency and method of growth, availability, economic efficiency, protection of soil and storing water, and pollution prevention were considered as secondary criteria for final priorities in fuzzy AHP method. Considering environmental and the future economic and social uses of the post-mined landscape, we have demonstrated that the best candidate for revegetation are Artemisia sieberi, Salsola yazdiana, Halophytes types, and Zygophyllum.

\section{Acknowledgement}

The author would like to thank Mr. Kazem Dashtakian, Vahid Mohammadi and Mohammad Abolghasemi who provided their expertise as well as required data of plant types in Yazd province.

All work was done under appropriate intellectual property agreements assuring unrestricted academic freedom to report all results of this research work.

\section{References}

Aydogan E.K., 2011. Performance measurement model for Turkish aviation firms using the rough-AHP and TOPSIS methods under fuzzy environment. Expert Systems with Applications, 38: 3992-3998.

Abolghasemi M., Mirhoseini A., Dashtakian K., 2004. Vegetation types of Ravar-Bahabad area, Yazd Research Institute of Forest and Rangelands, 99 p, (in Persian).

Akbari A., Osanloo M., Hamidian H., 2006. Selecting post mining land use through analytical hierarchy processing method: case study in Sungun copper open pit mine of Iran. Proc. of the fifteen Int. Symposium on Mine Planning and Equipment Selection (MPES 2006), Torino, Italy, 245-252.

Alavi I., Akbari D.A., Parsaei M., 2011. Plant type selection for Sarcheshmeh copper mine reclamation by Fuzzy-AHP method. BLOUR Science and Expertism Magazine, Amirkabir University of Technology, 29, 10-17, (in Persian).

Alavi I., Alinejad R.H., Sadegh Zadeh M., 2011. Prioritizing crescive plant species in Choghart iron mine desert region (Used method: Fuzzy AHP). Australian Journal of Basic and Applied Sciences, 5(12), 1075-1078.

Bangian A.H., Osanloo M., 2008. Multi attribute decision model for plant species selection in mine reclamation plans: Case study Sungun copper mine. Post-Mining, February 6-8, 1-11, (in Persian).

Bellman R.E., Zadeh L.A., 1977. Local and fuzzy logics. Modern Uses of Multiple-valued Logic, Kluwer, Boston, 158-165.

Boender C.G.E., de grann J.G., Lootsma F.A., 1989. Multicriteria decision analysis with fuzzy pair-wise comparison. Fuzzy Sets and Systems, 29(2): 133-143.

Bojadziev G., Bojadziev M., 1998. Fuzzy sets and fuzzy logic applications. World Scientific, Singapore, ISBN: 978981-283-069-2 (ebook), 300 p.

Buckley J., 1985. Fuzzy hierarchical analysis. Fuzzy Sets and Systems, 17, 233-247.

Chang D.Y., 1992. Extent analysis and synthetic decision. Optimisation Techniques and Applications, Vol. 1, World Scientific, Singapore, 352 p.

Chang D.Y., 1996. Applications of the extent analysis method on Fuzzy AHP. European Journal of Operational Research, 95, 649-655.

Chien-Chang C., 2011. Evaluating the quality of airport service using Fuzzy multi-criteria decision making method: a case study of Taiwanese airports. Expert Systems, 29(3), 246-260. 
Dashtakian K., Ekhtesasi M.R., Rad M.H., 2000. Vegetation types of Ardekan-Meybod area. Tehran Research Institute of Forest and Rangelands, 234, 93, (in Persian).

Dashtakian K., Baghestani Maybodi N., Rad M.H., Abolghasemi M., 2001. Vegetation types of Yazd area. Tehran Research Institute of Forest and Rangelands, 286, 125, (in Persian).

Dashtakian K., Khosroshahi M., 2002. Identification and introduction of desert plant species in Yazd province. Iranian journal of Rang and Desert Research, 11(4), 383-409, (in Persian).

Dashtakian K., Rad M.H., Abolghasemi M., 2002. Vegetation types of Abade area. Tehran Research Institute of Forest and Rangeland, 304, 115, (in Persian).

Deng H., 1999. Multicriteria analysis with Fuzzy pair-wise comparison. International Journal of Approximate Reasoning, 21, 215-231.

Ertuğrul I., Karakaşoğlu N., 2006. Fuzzy TOPSIS method for academic member selection in engineering faculty. International Joint Conferences on Computer, Information, and Systems Sciences, and Engineering (CISSE 06), 4-14.

Ertuğrul I., Karakaşoğlu N., 2008. Comparison of fuzzy AHP and fuzzy TOPSIS method for facility location selection. International Journal of Advanced Manufacturing Technology, vol. 39(8), 783-795.

Ertuğrul I., Tuş A., 2007. Interactive fuzzy linear programming and an application sample at a mine firm. Fuzzy Optimization and Decision Making, 6, 29-49.

Ertuğrul I., 2011. Fuzzy group decision making for the selection of facility location. Group Decision and Negotiation, 20(6), 725-740.

Ghaderi Gh.,Tavakoli H., Yusoofi M., 2003. Vegetation types of Tabas area. Tehran Research Institute of Forest and Rangelands, 319, 99, (in Persian).

Hwang C.L., Yoon K., 1981. Multiple attributes decision making methods and applications. Springer, Berlin.

Kahraman C., Cebeci U., Ulukan Z., 2003. Multi-criteria supplier selection using Fuzzy AHP. Logistics Information Management, 16(6), 382-394.

Kahraman C., 2008. Multi-criteria decision making methods and fuzzy sets. Fuzzy Multi-Criteri Decision Making. Springer Science \& Business Media, LLC, 16: 1-18.

Laurence D., 2001. Classification of risk factors associated with mine closure. Mineral Resources Engineering, 10(3), 315-331.

Laurence D., 2006 Optimization of the mine closure process. Journal of Clear Production, 14, 285-298

Mousaei Sanjerehei M., Jafari M., Mataji A., Baghestani Meybodi N., 2013 Influence of environmental factors on distribution of plant species in Nodushan rangelands of Yazd province (Iran). DESERT, 18, 19-26.

Naghadehi M.Z., Mikaeil R., Ataei M., 2009 The application of fuzzy analytic hierarchy process (FAHP) approach to selection of optimum underground mining method for Jajarm Bauxite Mine, Iran. Expert Systems with Applications, 36(4), 8218-8226.

Osanloo M., 2002 Mine reclamation. Amirkabir University of Technology Publications, Tehran.

Rajput H.C., Milani A.S., Labun A., 2011. Including time dependency and ANOVA in decision-making using the revised fuzzy AHP: A case study on wafer fabrication process selection. (Case study). Applied Soft Computing Journal, 8(11), 5099-5109.

Reyhan M.K., Amiraslani F., 2006. Studying the relationship between vegetation and physicochemical properties of soil, Case study: Tabas region, Iran. Pakistan Journal of Nutrition, 5(2), 169-171.

Saaty T.L., 1980. The analytic hierarchy process, McGraw-Hill, New York.

Soltanmohammadi H., Osanloo M., Aghajani A.B., 2010 An analytical approach with a reliable logic and a ranking policy for post-mining land-use determination. Land Use Policy, 27, 364-372.

Torlak G., Sevkil M., Sanal M., Zaim S., 2011. Analyzing business competition by using fuzzy TOPSIS method: An example of Turkish domestic airline industry. Expert System with Applications, 38, 3396-3406.

Vahdani B., Hadipour H., 2010. Extention of the ELECTRE method based on interval-valued fuzzy set. Soft Computing. http://dx.doi.org/10.1007/s00500-010-0563-5.

Vaidya O.S., Kumar S., 2006. Analytic hierarchy process: an overview of applications. European Journal of Operational Research, 169, 1-29.

Van Laarhoven P.J.M., Pedrcyz W., 1983. A Fuzzy extension of Saaty's priority theory. Fuzzy Sets and Systems, 11, $229-241$. 
728

Wang Y.M, Elhag T.M.S., 2006. Fuzzy TOPSIS method based on alpha level sets with an application to bridge risk assessment. Expert Systems with Applications, 31, 309-319.

Wang T.C., Chen Y.H., 2007. Applying consistent fuzzy preference relations to partnership selection. Omega, 35, $384-388$

Xia L.U., Zhen H.U., 2007. Vegetation growth monitoring under coal exploitation stress by remote sensing in the Bulianta coal mining area. Institute of Land Reclamation and Ecological Restoration, China University of Mining \& Technology, Beijing, 17(4), 0479-0483.

Zadeh L.A., 1965. Fuzzy sets. Information Control, 8, 338-353.

Zadeh L.A., 1975. The concept of a linguistic variable and its application to approximate reasoning. Information Sciences, 8, 199-249.

Zimmermann H.J., 1992. Fuzzy set theory and its applications. Modern uses of multiple-valued logic, Kluwer, Boston, 412. 